\title{
Production of sprouted garlic powder
}

\author{
Thanh T. Le ${ }^{1 *}$, Phong N. Le ${ }^{2}$, Phuoc H. Le ${ }^{2}$, Tri M. T. Le ${ }^{2}$, \& Trang T. T. Nguyen ${ }^{2}$ \\ ${ }^{1}$ Faculty of Food Science and Technology, Nong Lam University, Ho Chi Minh City, Vietnam \\ ${ }^{2}$ Faculty of Food Science and Technology, Nong Lam University, Ninh Thuan, Vietnam
}

\begin{abstract}
ARTICLE INFO
Research Paper

Received: November 02, 2018

Revised: February 26, 2019

Accepted: March 05, 2019
\end{abstract}

Keywords

Colletotrichum gloeosporioides

Garlic powder

Heat-pump drying

Sprouted garlic

\section{${ }^{*}$ Corresponding author}

Le Thi Thanh

Email: lethanh@hcmuaf.edu.vn

\begin{abstract}
Sprouting garlic is considered as a high phytochemical product that exerts health benefit. This study aimed to develop spouting garlic powder from Phan Rang garlic. Three sprouting methods, including growing in the soil, water immersion under ambient temperature and incubating at $10^{\circ} \mathrm{C}$ were investigated. The results showed that sprouting on the soil was the best method, characterizing sprouting garlicwith the sprouting length of $39.6 \mathrm{~mm}$, total soluble solids of $17.1^{\circ} \mathrm{Bx}$, total acidity of $0.56 \%$, moisture content $74.51 \%$, and recovery rate $28.2 \%$. The inhibitory ability against Colletotrichum gloeosporioides of fresh garlic sprouted in the soil had been evaluated. The results showed that the extract at the concentration of $5,5 \%$ was the most effective, indicated by completely inhibiting Colletotrichum gloeosporioides. To produce sprouted garlic powder, three drying methods, including heat-pump drying, air drying and freezedrying, were examined. The freeze-drying method was the most appropriate method to produce sprouted garlic powder with high nutritional value and the least changes of physicochemical properties. The powder obtained from this method showed a high inhibitory ability against Colletotrichum gloeosporioides ( $88 \%$ and $100 \%$ inhibition at 1.5 and $2 \%$ sprouted garlic, respectively)
\end{abstract}

Cited as: Le, T. T., Le, P. N., Le, P. H., Le, T. T. M., \& Nguyen, T. T. T. (2019). Production of sprouted garlic powder. The Journal of Agriculture and Development 18(4), 81-89. 


\title{
Nghiên cứu quy trình chế biến bột mầm tỏi từ tỏi Phan Rang
}

\author{
Lê Thị Thanh ${ }^{1 *}$, Lê Nhã Phong ${ }^{2}$, Lê Hồng Phước ${ }^{2}$, \\ Lê Trần Minh Trí ${ }^{2} \&$ Nguyễn Thị Thanh Trang ${ }^{2}$ \\ ${ }^{1}$ Khoa Công Nghệ Thực Phẩm, Trường Đại Học Nông Lâm TP.HCM, TP. Hồ Chí Minh \\ ${ }^{2}$ Khoa Công Nghệ Thực Phẩm, Trường Đại Học Nông Lâm TP.HCM, Ninh Thuận
}

\section{THÔNG TIN BÀI BÁO}

Bài báo khoa học

Ngày nhận: 02/11/2018

Ngày chỉnh sửa: 26/02/2019

Ngày chấp nhận: 05/03/2019

Từ khóa

Colletotrichum gloeosporioides

Bột tỏi

Mầm tỏi

Sấy bơm nhiệt

*Tác giả liên hệ

Lê Thị Thanh

Email: lethanh@hcmuaf.edu.vn

\section{TÓM TẮT}

Đề tài được thực hiện nhằm đa dạng hóa sản phẩm và nâng cao giá trị sử dụng của tỏi Phan Rang. Đầu tiên, ba phương pháp làm mầm tỏi là trồng trên đất, ngâm nước và ủ ở nhiệt độ $10^{\circ} \mathrm{C}$ đã được nghiên cứu. Kết quả cho thấy phương pháp trồng trên đất tốt hơn hai phương pháp còn lại với chiều dài mầm tỏi $39,6 \pm 2,4 \mathrm{~mm}$, tổng hàm lượng chất rắn hòa tan $17,1 \pm 0,8^{0} \mathrm{Bx}$, axít tổng $0,56 \pm 0,06 \%$, ẩm độ $74,51 \pm 3,51 \%$ và tỉ lệ thu hồi mầm đạt $28,2 \pm 1,1 \%$. Tiếp theo, hiệu lực kháng nấm Colletotrichum gloeosporioides của mầm tỏi tươi trong điều kiện in vitro đã được khảo sát; kết quả cho thấy chiết xuất tỏi tươi nảy mầm ở nồng độ $5,5 \%$ ức chế hoàn toàn nấm $C$. gloeosporioides. Để tạo bột mầm tỏi, ba phương pháp sấy là bơm nhiệt, sấy nóng và sấy thăng hoa đã được khảo sát; kết quả cho thấy sấy thăng hoa là phương pháp thích hợp nhất, tạo sản phẩm có giá trị dinh dưỡng cao hơn, thành phần hóa lý trong tỏi nảy mầm giảm ít nhất trong ba phương pháp sấy. Cuối cùng, việc đánh giá hiệu lực kháng nấm C. gloeosporioides của bột mầm tỏi cho thấy nồng độ bột mầm tỏi 1,5\% trở lên có khả năng kháng nấm cao với tỉ lệ là $88 \%$, từ nồng độ $2 \%$ trở lên kháng nấm $100 \%$.

\section{1. Đắt Vấn Đề}

Tỏi là một trong những loại cây vừa làm gia vị vừa làm vị thuốc. Tỏi cùng với ớt và hạt tiêu giữ vai trò chính trong mặt hàng gia vị xuất khẩu của Việt Nam. Theo Hiệp hội rau hoa quả Việt Nam, hàng năm, tổng sản lượng tỏi xuất khẩu của cả nước khoảng 2000 tấn/năm, chủ yếu từ các vùng trồng tỏi nổi tiếng là Lý Sơn - Quảng Ngãi, Ninh Hải - Ninh Thuận, Hải Dương, Vĩnh Phúc và Bắc Ninh. Trong đó tỏi Phan Rang trồng ở Ninh Hải - Ninh Thuận nổi tiếng được nhiều người biết đến, với hương vị thơm cay nồng vô cùng đặc trưng hơn so với các nơi trồng khác.

Với khí hậu nhiệt đới ẩm gió mùa ở Việt Nam, độ ẩm không khí cao là điều kiện cho tỏi dễ mọc mầm. Không giống như khoai tây khi nảy mầm sẽ sinh ra độc tố, tỏi khi nảy mầm sẽ gia tăng một số hợp chất có lợi cho sức khỏe con người. Theo Zakarova \& ctv. (2014), tỏi đã mọc mầm năm ngày có hoạt tính chống oxy hóa mạnh và hàm lượng allicin cao hơn tỏi tươi. Quá trình nảy mầm của tỏi làm tăng khá nhiều các hợp chất có lợi để bảo vệ mầm chống lại các điều kiện bất lợi của môi trường, đặc biệt là hợp chất chống oxy hóa hay các kháng sinh tự nhiên (Zakarova \& ctv., 2014). Với việc gia tăng các hợp chất chống oxy hóa và kháng sinh tự nhiên, tỏi mọc mầm mang lại nhiều lợi ích đối với sức khỏe con người như chống lão hóa, tăng cường sức đề kháng, bảo vệ tim mạch và ngăn ngừa đột quy.

Không chỉ có lợi về mặt sức khỏe, tỏi còn được sử dụng dể tiêu diệt nhiều loài côn trùng gây hại, nấm bệnh trên cây trồng. Theo Hayat \& ctv. (2016), nghiên cứu về khả năng kháng nấm của dịch chiết tỏi cho thấy tỏi có tiềm năng kháng nấm trên phổ rộng và phytoalexin allicin là một trong những thành phần kháng nấm chính trong tỏi. Khi nảy mầm, tỏi sẽ sản sinh ra nhiều hợp chất phytoalexin để bảo vệ mầm tỏi khỏi côn trùng. Phytoalexin trong tỏi nảy mầm gây độc cho côn trùng nhưng lại có lợi cho sức khỏe con 
người. Với việc gia tăng các hoạt chất kháng khuẩn, tiêu diệt côn trùng, tỏi nảy mầm cho thấy tiềm năng trong việc ứng dụng trong bảo quản nông sản. Đề tài nhằm mục đích đa dạng hóa sản phẩm, nâng cao giá trị sử dụng, tạo ra sản phẩm bột tỏi có chất lượng cao và tốt cho sức khỏe.

\section{Vật Liệu và Phương Pháp Nghiên Cứu}

Tỏi Phan Rang là giống tỏi ta, trồng tại Ninh Hải - Ninh Thuận, được mua tại vựa tỏi Ninh Hải, Ninh Thuận.

Nấm Colletotrichum gloeosporioides được mua từ Viện Cây Ăn Quả Miền Nam.

Môi trường nuôi cấy vi sinh: potato dextrose agar (PDA) (Himedia - Ấn Độ).

Một số phương pháp phân tích: Ẩm độ được đo bằng máy sấy ẩm độ hồng ngoại (A\&D MX50 Nhật); tổng hàm lượng chất rắn hòa tan $\left({ }^{0} \mathrm{Bx}\right)$ được đo bằng khúc xạ kế (Atago - Nhật) với thang đo $0-33^{0} \mathrm{~B}$; hàm lượng axít tổng được xác định bằng cách chuẩn độ với $\mathrm{NaOH} 0,1 \mathrm{~N}$ (Tran \& ctv., 2004); hàm lượng polyphenol tổng được xác định bằng phương pháp Folin - Ciocalteau (Singleton \& ctv., 1999); chiều dài mầm được đo bằng thước kẹp kỹ thuật số (CD-6, Nhật), 02 số lẻ; khối lượng mầm được xác định bằng cân kỹ thuật số (Ohaus - Mỹ), 2 số lè; tỉ lệ ức chế nấm được tính bằng cách đo đường kính tản nấm (Noori \& Saud, 2012); màu sắc được đo bằng máy đo màu Minolta Chroma Meter (CR400, Nhật).

\subsection{Khảo sát ảnh hưởng của phương pháp làm mầm tỏi đến chất lượng của tỏi nảy mầm}

Tỏi được tách rời ra thành từng tép đơn, chọn kích cỡ đồng đều, loại bỏ những tép nhỏ lép. Ba phương pháp làm mầm tỏi là trồng đất, ngâm nước và ủ ở nhiệt độ $10^{\circ} \mathrm{C}$ đã được nghiên cứu, mỗi phương pháp lặp lại 3 lần, mỗi lần $1 \mathrm{~kg}$ tỏi tép đơn. Đối với phương pháp trồng đất, các tép tỏi được trồng trong thùng xốp, tưới nước 2 lần/ngày. Đối với phương pháp ngâm nước, các tép tỏi được xếp vào khay nhựa, đổ nước ngập một nửa tép tỏi và thay nước mỗi ngày. Đối với phương pháp ủ ở nhiệt độ mát, các tép tỏi được bóc vỏ, để vào rổ nhựa và đặt vào tủ lạnh có nhiệt độ $10^{\circ} \mathrm{C}$. Sau 3 ngày, tỏi nảy mầm được thu hoạch và tiến hành đánh giá các chỉ tiêu: ẩm độ, tổng hàm lượng chất rắn hòa tan, hàm lượng axít tổng, hàm lượng polyphenol tổng, chiều dài mầm, và khối lượng mầm để chọn ra phương pháp làm mầm tỏi tốt nhất.

\subsection{Khảo sát khả năng ức chế sinh trưởng nấm Colletotrichum gloesporiodes của tỏi tươi nảy mầm}

Theo Baghalian \& ctv. (2005), hàm lượng allicin trong tỏi là $0,16-13 \mathrm{mg} / \mathrm{g}$ và nồng độ allicin tối thiểu để kháng nấm từ $7 \mu \mathrm{g} / \mathrm{mL}$ (Hughes \& ctv., 1991). Như vậy lượng allicin cần có trong $50 \mathrm{~mL}$ môi trường để đạt nồng độ allicin kháng nấm tối thiểu là $0,35 \mathrm{mg}$ allicin. Dựa trên cách pha nước chiết tỏi của Hayat \& ctv. (2016): Nước chiết tỏi ban đầu có nồng độ $100 \%$, là mỗi $10 \mathrm{~g}$ tỏi được đồng nhất với $10 \mathrm{~g}$ nước cất $(1 \mathrm{~mL}$ dịch tỏi tương đương $1 \mathrm{~g}$ tỏi) và lượng allicin tối thiểu có trong dịch tỏi nồng độ $100 \%$ là $0,16 \mathrm{mg} / \mathrm{mL}$. Dựa vào công thức tính nồng độ kháng nấm, ta tính được nồng độ kháng nấm tối thiểu là 4,02\%. Từ cơ sở này, chúng tôi tiến hành pha và bổ sung dịch tỏi nảy mầm với các nồng độ $0 \%$ (đối chứng), $1,5 \%, 3,5 \%, 5,5 \%$ và $7,5 \%$ vào môi trường $\mathrm{PDA}$. Sau đó lấy các khoanh nấm 7 ngày tuổi có đường kính $4,81 \mathrm{~mm}$ cấy vào trung tâm đĩa môi trường trên, nuôi cấy trong điều kiện nhiệt độ phòng. Theo dõi và ghi nhận đường kính khuẩn lạc nấm Colletotrichum gloesporiodes bằng cách đo đường kính của tản nấm hàng ngày, bắt đầu sau khi cấy 1 ngày đến khi tản nấm mọc đầy đĩa đối chứng. Thí nghiệm được thực hiện 3 lần lặp lại. Khả năng kháng nấm được xác định như sau:

$$
\begin{aligned}
& \text { Tỉ lệ ức chế sinh trưởng }(\%)=\frac{\mathrm{DK}_{\mathrm{DC}}-\mathrm{DK}_{\mathrm{TN}}}{\mathrm{DK} K_{\mathrm{DC}}} \\
& \times 100 \%
\end{aligned}
$$

Với:

$\bigoplus_{Ð C}$ : Đường kính trung bình của tản nấm ở các đĩa đối chứng.

ĐK $_{\mathrm{TN}}$ : Đường kính trung bình của tản nấm ở các đĩa thí nghiệm.

\subsection{Khảo sát các phương pháp sấy ảnh hưởng đến chất lượng bột tỏi nảy mầm}

Tỏi nảy mầm được rửa sạch, lột vỏ, cắt rễ và xếp vào khay sấy. Ba phương pháp sấy: sấy nóng $\left(40^{\circ} \mathrm{C}, 50^{\circ} \mathrm{C}, 55^{\circ} \mathrm{C}\right)$, sấy bơm nhiệt $\left(30^{\circ} \mathrm{C}, 35^{\circ} \mathrm{C}\right.$, $40^{\circ} \mathrm{C}$ ) và sấy thăng hoa (14 giờ) đã được nghiên cứu. Mỗi phương pháp được thực hiện với 3 lần lặp lại, mỗi lần $1 \mathrm{~kg}$ tỏi nảy mầm. Tỏi sau khi sấy khô đạt ẩm độ < $6 \%$ sẽ được nghiền nhuyễn tạo bột tỏi nảy mầm. Đánh giá các chỉ tiêu tỉ lệ thu hồi, ẩm độ, polyphenol tổng, axít tổng và màu sắc. 
Tỉ lệ thu hồi sản phẩm được tính bằng phần trăm (\%) của khối lượng sản phẩm sau khi sấy so với khối lượng ban đầu theo công thức:

$$
\mathrm{H}=\frac{\mathrm{m}}{\mathrm{m}_{0}} \times 100 \%
$$

Với:

$\mathrm{m}_{0}$ : Khối lượng ban đầu $(\mathrm{g})$.

$\mathrm{m}$ : Khối lượng sau khi sấy (g).

2.4. Khảo sát khả năng kháng nấm Colletotrichum gloeosporioides của bột tỏi nảy mầm

Tương tự cách tính nồng độ kháng nấm của dịch tỏi tươii, dựa trên tỉ lệ thu hồi bột tỏi sấy thăng hoa là $22,51 \%$ và tính được hàm lượng allicin tối thiểu của bột tỏi sấy thăng hoa là 0,71 $\mathrm{mg} / \mathrm{g}$. Như vậy lượng bột tỏi cần cho vào môi trường để dạt nồng độ kháng nấm tối thiểu là $0,49 \mathrm{mg}$ và dựa vào công thức tính nồng độ kháng nấm, ta tính được nồng độ kháng nấm tối thiều là $0,9 \%$. Bột tỏi nảy mầm sẽ được ngâm với nước cất theo tỉ lệ 1:4, lọc lấy phần dịch. Bổ sung dịch bột tỏi nảy mầm vào môi trường nuôi $\mathrm{PDA}$ để đạt các nồng độ $1 \%, 1,5 \%$ và $2 \%$ và đổ đĩa. Các khoanh nấm 7 ngày tuổi có đường kính $6,86 \mathrm{~mm}$ được cấy vào trung tâm đĩa môi trường, nuôi cấy trong điều kiện nhiệt độ phòng. Theo dõi và ghi nhận đường kính khuẩn lạc nấm Colletotrichum gloesporiodes bằng cách đo đường kính của tản nấm hàng ngày, bắt đầu sau khi cấy 1 ngày đến khi tản nấm mọc đầy đĩa đối chứng. Thí nghiệm được thực hiện 3 lần lặp lại. Khả năng kháng nấm của bột mầm tỏi được xác định qua tỉ lệ ức chế sinh trưởng (\%) tương tự như dịch tỏi tươi nảy mầm.

\subsection{Phương pháp phân tích xử lí số liệu}

Số liệu được thu thập và tổng hợp bằng phần mềm Excel 2016, xử lí thống kê và phân tích phương sai ANOVA bằng phần mềm JMP 10.0.

\section{Kết Quả và Thảo Luận}

\section{1. Ảnh hưởng phương pháp làm mầm tỏi đến chất lượng của tỏi nảy mầm}

Tỏi là loại gia vị có ẩm độ thương phẩm từ 64 $66 \%$. Trong quá trình bảo quản, tỏi dễ mọc mầm khi gặp điều kiện ẩm ướt. Do đó, qua khảo sát sơ bộ sàng lọc các điều kiện dễ mọc mầm của tỏi, chúng tôi đã chọn và tiến hành thử nghiệm 3 phương pháp làm mầm tỏi; đó là trồng trong đất, ngâm nước và ủ trong tủ lạnh ở $10^{0} \mathrm{C}$. Chất lượng mầm tỏi đã được đánh giá và kết quả được trình bày trong Bảng 1 .

Qua Bảng 1 và xử lý thống kê, chúng tôi nhận thấy tổng hàm lượng chất rắn hòa tan, axít tổng và ẩm độ giữa 3 phương pháp làm mầm không có sự khác biệt ý nghĩa ở độ tin cậy $95 \%(P>$ $0,05)$. Điều này cho thấy phương pháp làm mầm không có ảnh hưởng đến hàm lượng chất khô hòa tan, xít tổng và ẩm độ của mầm tỏi. Chiều dài mầm ở 3 phương pháp có sự khác biệt ý nghĩa về mặt thống kê ở độ tin cậy $95 \%$. Trong đó, chiều dài mầm của phương pháp trồng đất và phương pháp ngâm nước không có sự khác biệt nhau $(P$ $>0,05)$. Chiều dài mầm của phương pháp để tủ lạnh so với 2 phương pháp trồng đất và ngâm nước có sự khác biệt ý nghĩa thống kê ở độ tin cậy $95 \%$. Điều này cho thấy phương pháp nảy mầm có ảnh hưởng đến tốc độ nảy mầm của tỏi. Sau 3 ngày lên mầm, tỏi được lên mầm theo phương pháp trồng đất và phương pháp ngâm nước có mầm dài và có xu hướng mọc lá, còn tỏi được lên mầm theo phương pháp để tủ lạnh lên mầm chậm hơn và có mầm ngắn hơn.

Kết quả ở Bảng 2 cho thấy chiều dài tổng, axít tổng, ẩm độ, polyphenol và khối lượng mầm của 3 phương pháp không có sự khác biệt ý nghĩa về mặt thống kê ở độ tin cậy 95\%. Tuy không có sự khác biệt nhưng hàm lượng polyphenol của tỏi nảy mầm ở phương pháp trồng đất cao hơn so với 2 phương pháp còn lại, đạt $2,65 \mathrm{mg} / \mathrm{g}$. Lượng polyphenol có trong tỏi tươi nguyên liệu ban đầu đạt $2,32(\mathrm{mg} / \mathrm{g})$ ít hơn so với lượng polyphenol có trong tỏi nảy mầm theo phương pháp trồng đất là $2,65(\mathrm{mg} / \mathrm{g})$. Qua đó, cho thấy quá trình nảy mầm của tỏi làm tăng lượng polyphenol có trong tỏi. Về tổng hàm lượng chất rắn hòa tan, phương pháp trồng đất và ngâm nước cho tỏi có tổng hàm lượng chất rắn hòa tan thấp hơn phương pháp để tủ lạnh, điều này cho thấy trong quá trình mọc mầm, tỏi ở hai phương pháp này hấp thụ nhiều nước hơn, dẫn tới hàm lượng chất khô hòa tan trong tỏi giảm xuống. Đồng thời, trong quá trình tiến hành thí nghiệm, tỏi được nảy mầm bằng phương pháp ngâm nước dễ bị nhiễm mốc đen, làm giảm khối lượng thu được do phải loại bỏ phần tỏi bị mốc. Như vậy, từ các kết quả khảo sát, chúng tôi chọn phương pháp làm mầm tỏi là phương pháp trồng đất. Phương pháp này cho tốc độ lên mầm nhanh và khối lượng mầm thu 
Bảng 1. Thành phần hóa lý của mầm tỏi sau khi lên mầm bằng 3 phương pháp

\begin{tabular}{|c|c|c|c|}
\hline Chỉ tiêu & Trồng dất & Ngâm nước & Để tủ lạnh $10^{0} \mathrm{C}$ \\
\hline Chiều dài mầm (mm) & $39,62^{\mathrm{a}} \pm 2,39$ & $38,29^{\mathrm{a}} \pm 4,07$ & $23,55^{\mathrm{b}} \pm 7,17$ \\
\hline Tổng hàm lượng chất rắn hòa tan (\%) & $8,78^{\mathrm{a}} \pm 0,84$ & $8,67^{\mathrm{a}} \pm 0,67$ & $8,67^{\mathrm{a}} \pm 1,15$ \\
\hline Axít tổng (\%) & $0,53^{\mathrm{a}} \pm 0,11$ & $0,56^{\mathrm{a}} \pm 0,21$ & $0,63 \mathrm{a} \pm 0,24$ \\
\hline Ẩm độ $(\%)$ & $88,10^{\mathrm{a}} \pm 1,55$ & $87,29^{\mathrm{a}} \pm 2,71$ & $87,13^{\mathrm{a}} \pm 1,83$ \\
\hline
\end{tabular}

Bảng 2. Thành phần hóa lý của tỏi nảy mầm sau khi lên mầm bằng 3 phương pháp

\begin{tabular}{lccc}
\hline Chỉ tiêu & Trồng đất & Ngâm nước & Ủ ở $10^{0} \mathrm{C}$ \\
\hline Chiều dài mầm $(\mathrm{mm})$ & $72,33^{\mathrm{a}} \pm 7,67$ & $66,22^{\mathrm{a}} \pm 10,63$ & $46,93^{\mathrm{a}} \pm 20,46$ \\
Độ Brix $(\%)$ & $17,6^{\mathrm{a}} \pm 0,74$ & $17,4^{\mathrm{a}} \pm 0,20$ & $21,9^{\mathrm{b}} \pm 0,19$ \\
Axít tổng $(\%)$ & $0,56^{\mathrm{a}} \pm 0,06$ & $0,56^{\mathrm{a}} \pm 0,05$ & $0,63^{\mathrm{a}} \pm 0,03$ \\
Ầm độ $(\%)$ & $74,51^{\mathrm{a}} \pm 3,51$ & $72,84^{\mathrm{a}} \pm 3,25$ & $72.67^{\mathrm{a}} \pm 3,23$ \\
Polyphenol $(\mathrm{mg} / \mathrm{g})$ & $2,65^{\mathrm{a}} \pm 0,11$ & $2,59^{\mathrm{a}} \pm 0,05$ & $2,29^{\mathrm{a}} \pm 0,37$ \\
Khối lượng mầm $(\mathrm{g})$ & $283,33^{\mathrm{a}} \pm 34,14$ & $241,77^{\mathrm{a}} \pm 34,84$ & $249,47^{\mathrm{a}} \pm 18,76$ \\
\hline
\end{tabular}

a-b Trong cùng 1 hàng, các số có cùng ký tự giống nhau thì khác biệt không có ý nghĩa về mặt thống kê ở độ tin cậy $95 \%(P>0,05)$.

hồi tốt hơn hai phương pháp còn lại.

\subsection{Khả năng ức chế sinh trưởng nấm Col- letotrichum gloesporiodes của tỏi nảy mầm}

Qua kết quả Hình 1 và 2 cho thấy, nồng độ 1,5\% hoàn toàn không có khả năng ức chế nấm Colletotrichum gloeosporioides, tốc độ tản nấm phát triển gần như tương đương với nghiệm thức đối chứng $(0 \%$ dịch tỏi nảy mầm). Các nồng độ $3,5 \%, 5,5 \%$ và $7,5 \%$ đều có khả năng ức chế sinh trưởng của nấm Colletotrichum gloeosporioides, nhưng với tỷ lệ ức chế ở mức độ khác nhau, trong đó nồng độ dịch tỏi $5,5 \%$ và $7,5 \%$ có khả năng ức chế cao nhất đạt tỷ lệ $100 \%$, trong khi nồng độ $3,5 \%$ chỉ ức chế cao nhất là $34,4 \%$. Khi nồng độ dịch tỏi càng cao, các hợp chất polyphenol, allicin càng cao do đó khả năng ức chế nấm càng cao. Như vậy, qua kết quả khảo sát giữa các nồng độ $1,5 \%, 3,5 \%, 5,5 \%, 7,5 \%$ và mẫu đối chứng cho thấy với nồng độ dịch tỏi nảy mầm từ $5,5 \%$ trở lên có khả năng ức chế hoàn toàn nấm Colletotrichum gloeosporioides gây bệnh thán thư trên xoài.

\section{3. Ảnh hưởng của phương pháp sấy đến chất lượng bột tỏi nảy mầm}

\subsubsection{Thành phần hóa lý}

Thành phần hóa lý của sản phẩm bị ảnh hưởng rất nhiều bởi điều kiện sấy. Do đó, để tìm ra được phương pháp sấy thích hợp, thành phần hóa lý của bột tỏi nảy mầm sau khi sấy bằng ba phương pháp (sấy không khí nóng, sấy bơm nhiệt, sây thăng hoa) đã được phân tích và kết quả được thể hiện qua Bảng 3 .

Qua Bảng 3 và kết quả xử lý thống kê cho thấy, các chỉ tiêu hóa lý về ẩm độ, acid tổng, tỉ lệ thu hồi và hàm lượng polyphenol ở 3 phương pháp sấy nóng, sấy bơm nhiệt và sấy thăng hoa đều khác biệt có ý nghĩa về mặt thống kê (với $P<$ $0,05)$, chứng tỏ phương pháp sấy rất ảnh hưởng đến chất lượng sản phẩm. Đối với ẩm độ, tỏi được sấy bằng phương pháp sấy khí nóng có ẩm độ khoảng $11 \%$. Tỏi được sấy bằng phương pháp sấy bơm nhiệt có ẩm độ đạt khoảng 20 - 21\%. Tỏi được sấy bằng phương pháp sấy thăng hoa có ẩm độ thấp nhất, đạt $6,92 \%$. Với việc đạt ẩm độ thấp hơn, tỏi sấy thăng hoa dễ dàng nghiền mịn hơn so với 2 phương pháp còn lại. Đối với tỉ lệ thu hồi, vì đạt ẩm độ thấp nhất trong các phương pháp sấy nên tỉ lệ thu hồi của phương pháp sấy thăng hoa cũng thấp nhất. Phương pháp sấy bơm nhiệt có tỉ lệ thu hồi cao nhất, dao động trong khoảng $30 \%$ vì tỏi được sấy bằng phương pháp này có ẩm độ cao nhất. Về axít tổng, tỏi sấy bằng phương pháp sấy thăng hoa giữ lại được hàm lượng axít cao nhất là $2 \%$, tiếp theo là phương pháp sấy bơm nhiệt $40 \mathrm{oC}$ với hàm lượng axít đạt $1,22 \%$. Tỏi sấy bằng phương pháp sấy không khí nóng $40^{\circ} \mathrm{C}$, sây bơm nhiệt ở $30^{\circ} \mathrm{C}$ và $35^{\circ} \mathrm{C}$ có hàm lượng axít thấp nhất, dao động trong khoảng $0,9 \%$. Điều 


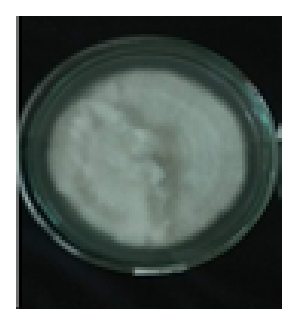

ĐC

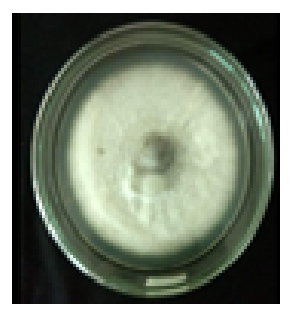

$1,5 \%$

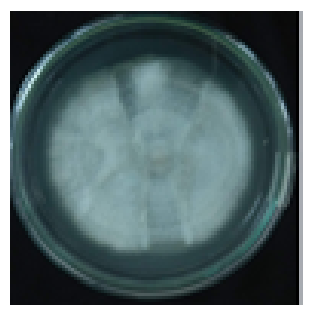

$3,5 \%$

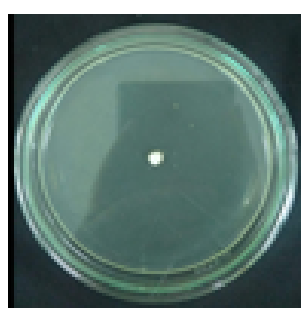

$5,5 \%$

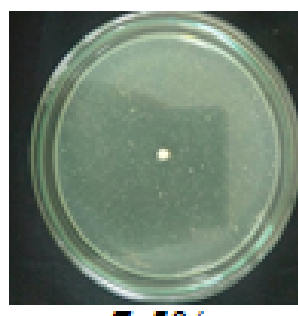

$7,5 \%$

Hình 1. Tản nấm Colletotrichum gloeosporioides của các nghiệm thức sau 11 ngày.

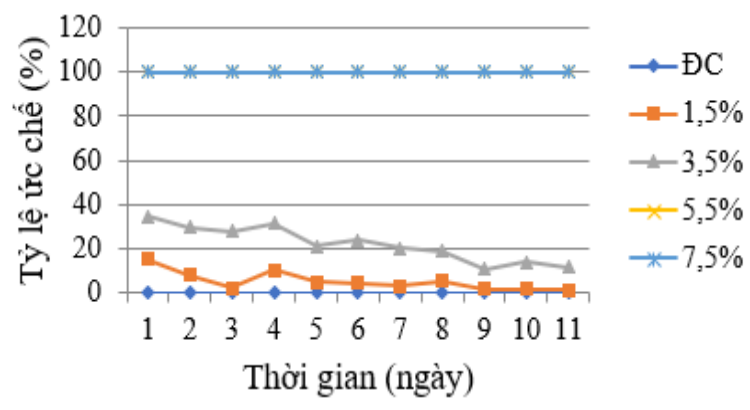

Hình 2. Ảnh hưởng của nồng độ dịch tỏi nảy mầm đến tỷ lệ ức chế nấm theo thời gian.

này cho thấy, đối với phương pháp sấy không khí nóng và sấy bơm nhiệt, thời gian sấy càng dài thì lượng acid mất đi càng nhiều. Về polyphenol, tỏi sấy bằng phương pháp sấy thăng hoa có hàm lượng polyphenol cao nhất, đạt $2,84 \mathrm{mg} / \mathrm{g}$. Trong khi đó, tỏi sấy bằng phương pháp sấy bơm nhiệt có hàm lượng polyphenol thấp nhất, dao động trong khoảng 0,95 - 1,61 mg/g. Điều này cho thấy, phương pháp sấy thăng hoa rất tối ưu trong việc giữ lại thành phần polyphenol của tỏi.

\subsubsection{Quá trình giảm ẩm độ của phương pháp sấy khí nóng}

Với ẩm độ ban đầu của tỏi nảy mầm là 74,51\%, khi sấy bằng phương pháp sấy không khí nóng, ẩm độ giảm còn khoảng $11 \%$. Qua kết quả Hình 3 cho thấy sự tương quan tỉ lệ thuận giữa nhiệt độ và thời gian sấy, nhiệt độ càng cao thì thời gian sấy càng ngắn, cư thể khi sấy ở $55^{\circ} \mathrm{C}$ mất 10 giờ ẩm độ đạt $11,06 \%$ trong khi sấy ở $40^{0} \mathrm{C}$ mất 36 giờ ẩm độ đạt $11,65 \%$. Khi nhiệt độ sấy thấp, tốc độ làm khô chậm, độ ẩm trong sản phẩm cao, enzyme cũng bị giảm hoạt tính do quá trình tự thủy phân theo thời gian. Khi sấy ở nhiệt độ quá cao, protein bị biến tính, nếu sấy ở nhiệt độ cao hơn nữa sẽ xảy ra các phản ứng Maillard, làm giảm chất lượng sản phẩm. Với ẩm độ dao động trong khoảng $11 \%$, tỏi sau quá trình sấy khi xay thành dạng bột mịn, các hạt bột tỏi dễ kết dính với nhau, làm cho sản phẩm không đồng nhất.

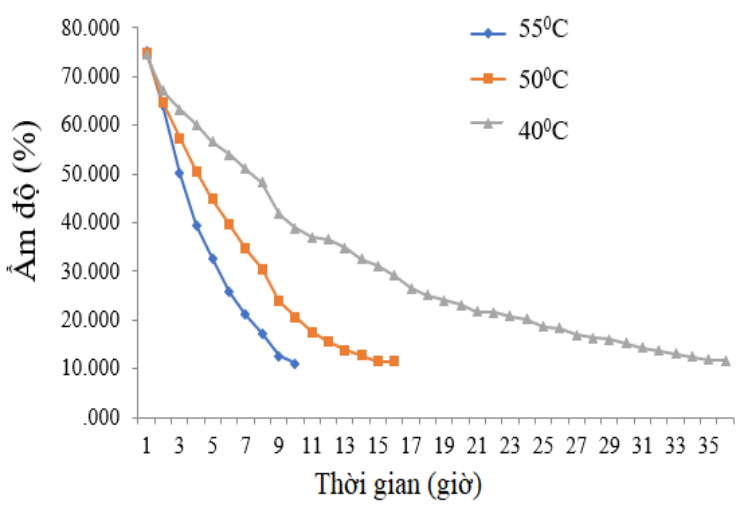

Hình 3. Quá trình giảm ẩm của tỏi bằng phương pháp sấy không khí nóng.

\subsubsection{Quá trình giảm ẩm độ của phương pháp sấy khí nóng}

Sấy ở nhiệt độ càng thấp thì hàm ẩm trong nguyên liệu giảm chậm do sự chênh lệch áp suất hơi nước trên bề mặt nguyên liệu và áp suất riêng phần trong không khí nhỏ nên tốc độ thoát ẩm chậm làm kéo dài thời gian sấy, do đó trên Hình 4 cho thấy ẩm độ của sản phẩm giảm dần từ khoảng $75 \%$ xuống đến khoảng $21 \%$. Nhiệt độ sấy thấp nên thời gian sấy kéo dài, cụ thể là ở nhiệt độ $30^{\circ} \mathrm{C}$ phải mất hơn 48 giờ mới đạt độ ẩm $21,79 \%$. Khi tăng nhiệt độ sấy lên thì tốc độ làm khô cũng tăng lên do lúc này nguyên liệu được nâng nhiệt, quá trình khuếch tán ẩm ra bên ngoài tăng nên khi sấy ở nhiệt độ $40^{\circ} \mathrm{C}$ thì mất tới 36 giờ mới thu được sản phẩm đạt độ ẩm ở mức $20,13 \%$. Phương pháp sấy bơm nhiệt này cho sản phẩm bột tỏi còn 


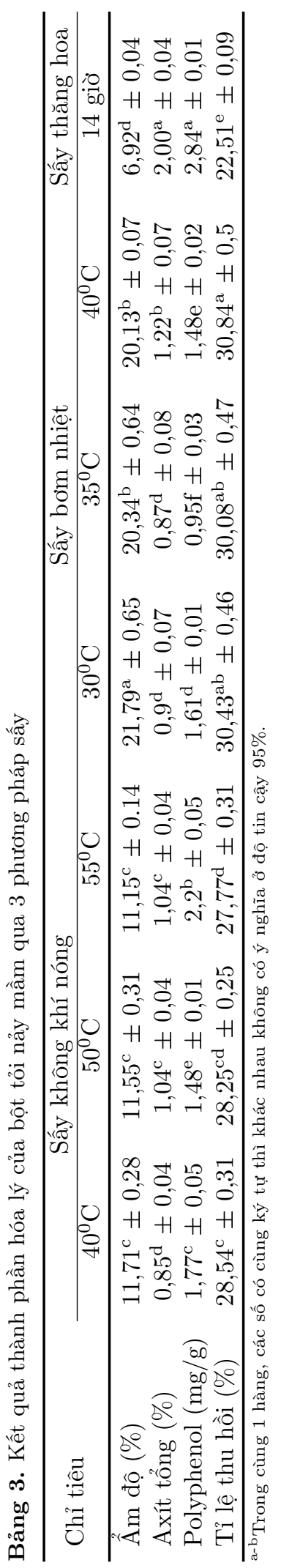

độ ẩm rất cao, không đạt độ ẩm của sản phẩm bột củ $(5-12 \%)$ mà chúng tôi mong muốn. Như vậy, qua kết quả các chỉ tiêu hóa lý khảo sát giữa các phương pháp sấy cho thấy phương pháp sấy thăng hoa là tối ưu nhất, thời gian sấy khoảng 14 giờ, bột tỏi nảy mầm có ẩm độ thấp $(6,92 \%)$ tốt cho quá trình nghiền tạo bột và bảo quản, bên cạnh đó độ màu sắc sáng nhất, giữ được lượng axít tổng cao, phần trăm hàm lượng polyphenol bị hao hụt ít hơn so với 2 phương pháp sấy khí nóng và sấy bơm nhiệt.

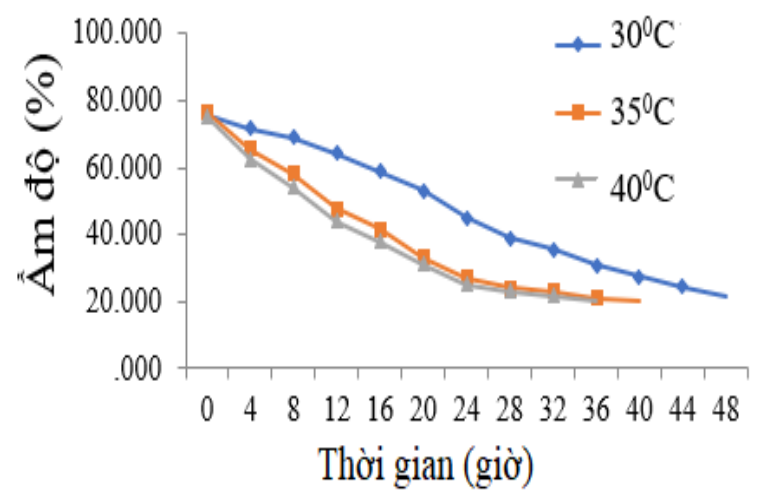

Hình 4. Quá trình giảm ẩm của tỏi với phương pháp sấy bơm nhiệt.

\subsubsection{Khả năng kháng nấm Colletotrichum gloeosporioides của bột tỏi nảy mầm}

Qua kết quả Hình 5 và 6 cho thấy 3 nồng độ bổ sung bột tỏi là $1 \%, 1,5 \%$ và $2 \%$ đều có khả năng ức chế sinh trưởng của nấm Colletotrichum gloeosporioides nhưng với tî̉ lệ ức chế khác nhau và khả năng ức chế có xu hướng càng tăng khi nồng độ bột tỏi càng tăng. Trong đó nồng độ $2 \%$ có khả năng ức chế $100 \%$ nấm Colletotrichum gloeosporioides, nồng độ $1 \%$ chỉ ức chế cao nhất là $63,1 \%$ và nồng độ $1,5 \%$ có khả năng ức chế cao nhất là $83,15 \%$. Khi xét tỉ lệ ức chế nấm Colletotrichum gloeosporioides của từng nồng độ dịch bột tỏi theo thời gian cho thấy có sự khác biệt nhau qua từng ngày. Trong 09 ngày theo dõi, kết quả cho thấy nồng độ $1,5 \%$ và $2 \%$ có khả năng ức chế nấm mạnh từ ngày thứ 3 trở đi, tỉ lệ ức chế tăng qua từng ngày cho đến ngày thứ 9 . Đối với nồng độ $1 \%$ có khả năng ức chế nấm mạnh vào giai đoạn từ ngày thứ 3 đến ngày thứ 7 và mạnh nhất vào ngày thứ 5 , sau đó tỉ lệ ức chế có sự chậm lại và giảm dần. Như vậy, qua tỷ lệ ức chế sinh trưởng nấm Colletotrichum gloeosporioides sau 09 ngày theo dõi, chúng tôi nhận thấy 

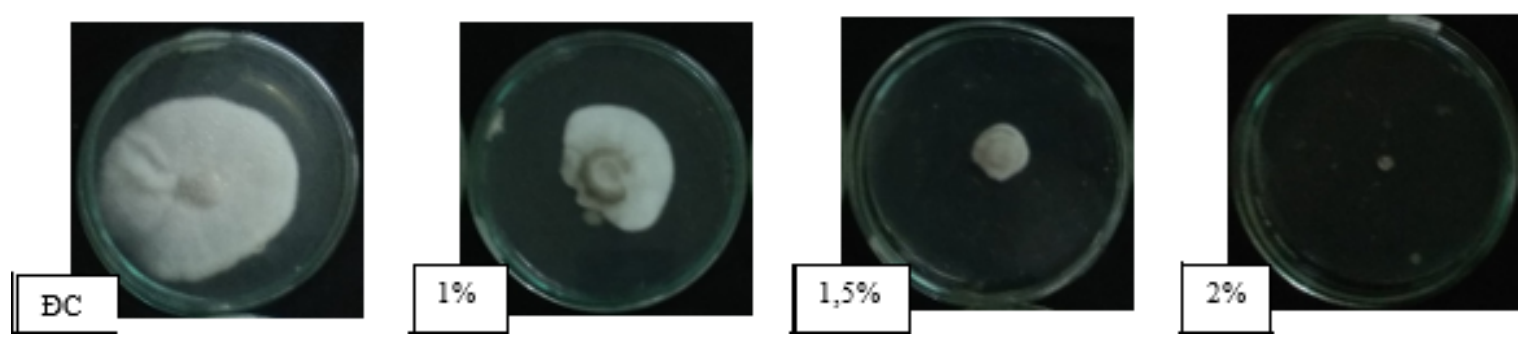

Hình 5. Tản nấm Colletotrichum gloeosporioides của các nghiệm thức sau 09 ngày.

nồng độ dịch bột tỏi nảy mầm từ $2 \%$ ức chế nấm Colletotrichum gloeosporioides hoàn toàn.

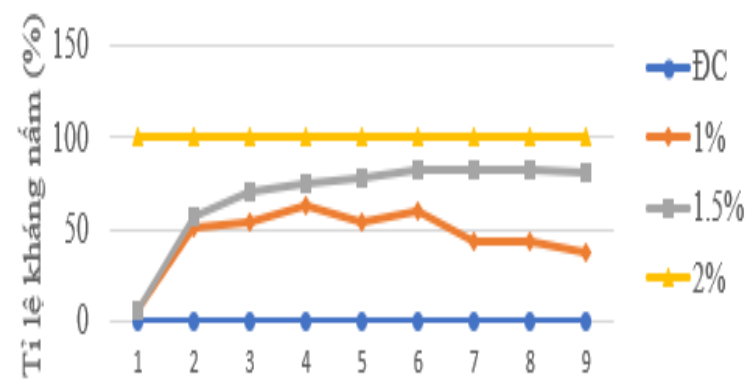

Thời gian (ngày)

Hình 6. Ảnh hưởng của nồng độ dịch bột tỏi đến sinh trưởng của nấm Colletotrichum gloeosporioides.

\subsubsection{Quy trình chế biến}

Quy trình chế biến bột tỏi nảy mầm thể hiện ở Hình 7.

Tỏi Phan Rang đã phơi khô, không bị mốc, bị óp, được tách rời từng tép và trồng trong đất ẩm. Tỏi được trồng với mật độ là các tép tỏi cách nhau $2 \mathrm{~cm}$ và vùi dưới đất $5 \mathrm{~cm}$. Tỏi mọc mầm sau 3 ngày sẽ được rửa sạch, chọn lọc tỏi mầm kích thước đồng đều, tách lớp vỏ ngoài, cắt rễ và rửa sạch lại lần nữa trước khi cấp đông, xử lý cho quá trình sấy thăng hoa. Tỏi cấp đông sấy thăng hoa trong thời gian 14 giờ, đạt ẩm độ khoảng $6 \%$ và nghiền tạo bột tỏi.

\section{Kết Luận và Kiến Nghị}

\subsection{Kết luận}

Sau khi tiến hành các thí nghiệm, chúng tôi có kết luận như sau: Phương pháp trồng đất là phương pháp làm mầm tỏi tối ưu nhất. Dịch

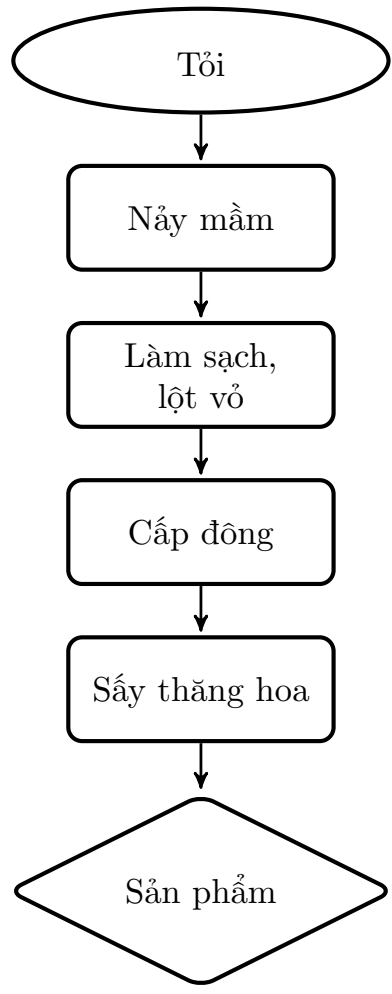

Hình 7. Quy trình chế biến bột tỏi nảy mầm.

tỏi nảy mầm tươi từ phương pháp trồng đất có khả năng ức chế hoàn toàn nấm Colletotrichum gloeosporioides ở nồng độ từ $5,5 \%$. Trong các phương pháp sấy tỏi đã tiến hành, phương pháp sấy thăng hoa là phương pháp tối ưu nhất và bột tỏi nảy mầm sau sấy có khả năng ức chế hoàn toàn nấm Colletotrichum gloeosporioides ở nồng độ từ $2 \%$.

\subsection{Kiến nghị}

Xác định hàm lượng allicin trong tỏi nảy mầm và khả năng kháng vi sinh vật khác của tỏi nảy 
mầm và bột tỏi nảy mầm.

\section{Tài Liệu Tham Khảo (References)}

Baghalian, K., Ziai, S. A., Naghavi, M. R., Badi, H. N., \& Khalighi, A. (2005). Evaluation of Allicin Content and Botanical Traits on Iranian Garlic (Allium sativum L.) Ecotypes. Scientia Horticulturae 103, 155-166.

Hughes, B. G., \& Lawson, L. D. (1991). Antimicrobial effects of Allium sativum L. (garlic), Allium ampeloprasum L. (elephant garlic) and Allium cepa L. (onion), garlic compounds and commercial garlic supplement products. Phytotherapy Research 5, 154-158.

Noori, M. S. S., \& Saud, H. M. (2012). Potential plant growth-promoting activity of Pseudomonas sp. isolated from paddy soil in Malaysia as biocontrol agent. Journal of Plants Pathology and Microbiology 3(2), 14.

Hayat, S., Cheng, Z., Ahmad, H., Ali, M., Chen, X., \& Wang, M. (2016). Garlic, from remedy to stumulant: Evaluation of antifungal potential reveals diversity in phytoalexin allicin content among garlic cultivars; allicin containing aqueous garlic extracts trigger antioxidants in cucumber. Frontier in Plant Science $7,1-15$.
Singleton, V. L., Orthofer, R., \& Lamuela-Raventós, R. M. (1999). Analysis of total phenols and other oxidation substrates and antioxidants by means of folinciocalteu reagent. Methods in Enzymology 299, 152178.

Tran, L. B., Ton, N. N. M., \& Dinh, N. T. T. (2004). Food chemistry laboratory. Ho Chi Minh City, Vietnam: Vietnam National University-Ho Chi Minh City Publishing House.

Zakarova, A., Seo, J. Y., Kim, H. Y., Kim, J. H., Shin, J. H., Cho, K. M., Lee, C. H., \& Kim, J. S. (2014). Garlic sprouting is associated with increased antioxidant activity and concomitant changes in the metabolite profile. Journal of Agricultural and Food Chemistry 62(8), $1875-1880$ 